\title{
Evaluations of Financial Performance Indicators Based on Factor Analysis in Automotive
}

\author{
Jana Hornungová1, František Milichovský2* \\ 1 Department of Economics, Faculty of Business and Management, Brno University of Technology, \\ CZ-61200 Brno, Kolejní 2906/4, Czech Republic \\ 2 Department of Management, Faculty of Business and Management, Brno University of Technology, \\ CZ-61200 Brno, Kolejní 2906/4, Czech Republic \\ *Corresponding author, e-mail: milichovsky@fbm.vutbr.cz
}

Received: 30 July 2017, Accepted: 26 October 2018, Published online: 28 January 2019

\begin{abstract}
The automotive industry is one of the most significant contributors to the economy of the European Union. This industry employs the largest number highly skilled labors and is a key driver of Europe's innovation and knowledge so it is an interesting area for research work. Data from 422 subjects in four parts of Europe (include twenty-five countries) have been analyzed. Authors used the factor analysis to eliminate information duplication and reduce dimensionality. At the same time, Pearson's chi-square test was used to find possible dependencies between observed factors and company size and region of the company. The research brings the conclusion that an alternative hypothesis is applied - all four defined connection between observed indexes and corporate size and region reach accurate values and there is confirmed dependency between them. At the end of the paper, the corresponding map was constructed for graphical representation of both row and column categories and variables. Western companies are at the top of the performance level. Vice versa, southern companies incline to the first quartile, what means they are not focused on performance measurement. The research is focused on the area of performance in the automotive industry in Europe region during last five years. The main aim of this paper is to find key indicators in grouped factors in the field of financial performance of automotive companies because performance is a crucial issue for all individuals and organizations.
\end{abstract}

Keywords

automotive, financial performance indicators, factor analysis, the correspondence map

\section{Introduction}

The European Union (EU) is the world's leading producer of motor vehicles. The automotive industry is one of the most significant contributors to the economy of the European Union. The presence of a vast base of the automotive industry in the European Union has contributed largely to the prosperity of Europe. The automotive industry in European Union is the largest provider of employment to people in Europe. The industry employs the largest number of highly skilled labors and is a key driver of Europe's innovation and knowledge.

The automotive industry is of great importance in the Czech Republic from the point of economic performance and labor market. Car manufacturers are one of the main employers in the industry sector. In addition to three main car companies (Škoda Auto, Hyundai Motor Manufacturing Czech, Toyota Peugeot Citroën
Automobile) and manufacturers of buses and trucks, a wide and diversified network of suppliers is involved. This fact, besides focus on many subjects on R \& D and design, makes the Czech Republic a compact car production center. Performance of the Czech car industry is characterized by the annual production of 118 vehicles per 1,000 inhabitants, thus making the Czech Republic the world's car power; the annual production of more than $1,000,000$ cars ranks the Czech Republic $16^{\text {th }}$ in the world. Production of cars is essential for the Czech economy; car industry participates in the Czech export with nearly $25 \%$, GDP around $7.4 \%$ (CSAS, 2015).

Organizational performance is the ultimate dependent variable of interest for researchers concerned with just about any area of management. Market competition for customers, inputs, and capital make organizational 
performance essential to the survival and success of the modern business (Richard et al., 2009). The definition of organizational performance is a surprisingly open question with few studies using consistent definitions and specific measures (Ehrenberger et al., 2015; Kirby, 2005). Performance is so common in management research that its structure and definition are rarely explicitly justified; instead, its appropriateness, in no matter what form, is unquestionably assumed (March and Sutton, 1997).

The main aim of this paper is to find key indicators in grouped factors in the field of financial performance of automotive companies because performance is a crucial issue for all individuals and organizations.

\section{Theoretical background}

Performance is a crucial issue for all individuals and organizations. Holsapple and $\mathrm{Wu}$ (2011) asserted that a set of unique resources owned by the firm (namely: valuable, rare, difficult to imitate, and irreplaceable by other resources) is the main driver of corporate performance. Moreover, excellent corporate performance is the key to competitive advantage.

One of the most important steps to measure and evaluate the success of the organization is its financial results; the growth and progress can be achieved only by the achievement of a certain performance. Financial performance is usually measured by profits and profitability ratios. One of the main objectives of the company is to survive in a competitive market; profit generation is included in such objective. The term "performance" is increasingly being used to explain various company terms such as growth, turnover, profitability, competitiveness (Colasse, 2009; Sebestova, 2012).

Performance and financial competitiveness represent a certain form of success or result of the action, leading to the success. Ratios used to measure performance and financial competitiveness are very diverse; some of them are classified as classical, some of them as modern. Within the framework of this "diagnostics" of the company performance, financial performance is evaluated from the point of ability to make a profit or is usually associated with its profitability; therefore, profitability ratios are usually accepted and used to measure performance (Monea and Guță, 2011).

Traditional financial indicators (calculated from accounting data) are still used today to evaluate performance; this approach to performance evaluation and comparison has been recognized as the most appropriate for a long period of time in spite of different accounting and financial indicators.
Since 1980 traditional methods have been facing various views, identifying contentious issues in the use of these models, resulting in the search for other opportunities for performance evaluation (Mohamed et al., 2014; Neely, 2004).

In order to measure profitability can be used two categories of indicators: the profit and profitability ratios. The profit is an indicator reflecting financial performances as an absolute measure, such as turnover, operational result, financial result, an extraordinary result, gross result or net result. The profitability ratios are used as a relative measure, such as economic profitability ratio, financial profitability ratio, commercial profitability ratio, or the used resources profitability ratio (Monea, Guță, 2011).

In the field of performance, the authors Richard et al. (2009) pursued a research; they analyzed 722 articles, in 213 of them some performance indicator was used. In around half of the cases, the performance was measured by a single indicator; the second half employed more indicators. Performance measured by accounting data $(53 \%)$ was mostly used. The authors divided indicators into three groups:

- Accounting measures - are the most common and readily available means of measuring organizational performance. The following indicators can be ranked among indicators coming out from the accounting data: Cash flow from operations, EBIT, EBITDA, Market share, Net operating profits, NOPAT, Profit margin, ROA, ROCE, ROE, ROI, ROIC, RONA, ROS, Return on total assets, Risk-adjusted return on capital, Sales, Sales growth, Variance in accounting profitability.

- Financial market measures - within the strategy, economics, and finance literature, financial market-based measures (most dominantly shareholder return) are the preferred instrument for characterizing organizational performance. Main financial market measures are Beta coefficient, Earnings-per-share, Jensen's alpha, Market value, Price-to-earnings ratio, Return on market-valued assets, Stock price, Total shareholder return, Tracking stocks. A major limitation of the use of financial market data in management research is that it evaluates the organization as a whole.

- Mixed accounting / financial market measures an advantage of these measures is that are better able to balance risk against operational performance issues that are sometimes lost in market measures. Examples of mixed measures are: Balanced scorecard, Cash flow per share, Cash flow return on investment, Cash value added, Discounted cash flows, Economic value 
added, Free cash flows, Internal rate of return, Marketto-book value, Market value added, Net present value, Shareholder value analysis, Warranted equity value, WACC, and Z-score (Richard et al., 2009).

Areas of concern, related to the management, investors, and creditors see the following Table 1, complete with the most frequently used methods of performance measurement.

Profit and loss statement, which representing the influence of managerial operational decisions on the economic results of the company, has been used to study company performance (in this case the information whether the company generates profit or loss). In consideration of these results, the balance must be extended to clarify certain important elements in the modification in the shareholders' capital with the aim to offer more detail information necessary to measure performance in the company. Information related to the company's performance, especially as regards its productivity, is used for (Elena, 2012):

- evaluation of potential modifications of the company's economic resources in a way to be influenced in the future. Information related to performance and mainly the ability of its change are immensely important for the decision-making process, e.g., the ability to forecast cash flows from the existing resources;

- declaration on efficiency in the use of new resources.

On the basis of the theoretical framework, this article focuses on the financial indicators of automotive companies, forming the part of a financial performance.

In general, measurements can be divided according to the type of key indicators and results. The measurable indicators should be divided according to their essence to several groups (Smith, 2008; Zakaria et al., 2011; Samsonowa et al., 2009):

- Result indicators are focused on achieving the objectives of indicators (Key Goal Indicators - KGI). They represent a measure of success and verification success. Indicate whether the goal has been achieved.

- Critical success factors (CSF) includes the elements, which are essential for businesses to achieve their goals. They are used to manage, control and trace of the actions, which are necessary to achieve results. Once aware of these critical success factors is to determine key performance indicators easier.

- Performance indicators (efficiency) are focused on performance measurement and its support (Key Performance Indicators - KPIs). They are used to quantify objectives to reflect the performance of a process or service. They are usually used for measuring the value, efficiency, quality, and customer satisfaction. Indicators, contained in KPIs, must reflect business objectives, must be measurable and should become a key to success.

- Key Result Indicators (KRIs) includes information about many activities which have done and if a company goes in the right direction. KRIs provide such information which is prepared mainly for top management.

- KPIs could help companies manage own priorities in various fields - environmental, governmental or social. These fields are linked with corporate strategy and usually include many non-financial indicators, for which exist relevant information (Kerzner, 2011).

Table 1 Performance indicators according to segments and perspectives (Helfert, 2006)

\begin{tabular}{|c|c|c|c|}
\hline \multirow{2}{*}{$\begin{array}{l}\text { Management, operational } \\
\text { analysis }\end{array}$} & Gross margin & Profit margin & Added value \\
\hline & Net revenue result & Structural analysis & Revenue leverage \\
\hline \multirow{2}{*}{$\begin{array}{l}\text { Investors / Shareholders } \\
\text { productivity }\end{array}$} & Social capital productivity & Net assets productivity & Share quotation increase \\
\hline & Earnings per share & Cash flow per share & \\
\hline Creditors, Liquidity & General liquidity & Acid test & Liquidity value \\
\hline Resource management & Stock turnover & Receivables turnover & Asset turnover \\
\hline \multirow{2}{*}{ Profit usage } & Dividends / Total assets & Dividend-coverage degree & Distribution / un-allocation ratio \\
\hline & Dividend per share & Dividend ratio & \\
\hline Financial leverage & Leverage degree & Financial stability & Financial autonomy \\
\hline \multirow{2}{*}{ Productivity } & Gross productivity & Net assets productivity & Net economic productivity \\
\hline & Economic value added & Economic profit & Cash-flow productivity \\
\hline Debt service & Fixed-expenses coverage degree & Cash-flow analysis & Debt-coverage degree \\
\hline
\end{tabular}


Parmenter (2010) adds to this topic, that performance metrics are usually a combination of Key result indicators (KRIs), Result indicators (RIs), Performance indicators (PIs) and Key performance indicators (KPIs). Harvey (2005) expressed to this matter in the sense that no matter which KPIs are used, these should mainly reflect the strategy, and should be regularly adapted to the changing business environment. Allio (2006) adds to metrics that good (well chosen) metrics facilitate the implementation of corporate strategies, while the bad (wrongly chosen) or no metrics, they can even implement the strategy to defend.

Germain et al. (2001) stated that performance control can be of two types: internal performance, which is related to issues such as cost, product quality, and profit level; and benchmarked performance, which compares cost, quality, customer satisfaction, and operations to a standard, such as the industry norm or the practices of its leaders.

Within the framework of the Czech environment, the authors Šiška and Lízalová (2011) sought for the most appropriate indicator to measure a long-term performance of the company. By cluster analysis, they identified two groups of the least mutually correlating indicators, i.e., profitability ratio and economic growth indicator. Return on assets and asset growth or the risk of yearon-year fluctuation, adjusted return-on-sales, and revenue growth proved to be the most appropriate indicators. Therefore, automakers have switched their attention to after sales business which proves to be a recession- resistance business, especially after the world financial crisis in 2008. Consequently, the after sales business has become increasingly important and is one of the main revenue and customer loyalty contributors.

\section{The situation in the automotive industry \\ 3.1 The automotive industry in European Union}

The automotive industry is crucial for Europe's prosperity. The motor vehicles, trailers, and semi-trailers manufacturing sector is dominated by two large subsectors, namely motor vehicle manufacturing (Group 29.1) and motor vehicle parts and accessories manufacturing (Group 29.3), which together contributed more than nine-tenths of the sector's employment and value added. The sector provides jobs for 12 million people and accounts for $4 \%$ of the EU's GDP. The EU is among the world's biggest producers of motor vehicles and the sector represents the largest private investor in research and development (R\&D). To strengthen the competitiveness of the EU automotive industry and preserve its global technological leadership, the European Commission supports global technological harmonization and provides funding for R\&D (European Commission, n.d.).

Sales have improved in the European Union since the financial downturn, but the E.U. auto industry is held hostage by local economies that are teetering on the edge of recession. In 2015, new car registrations in the E.U. rose 9.3 percent year-on-year, to 12.6 million units. But that is well below the record year of 2007 when more than 18 million vehicles were sold in the region. And the automakers are struggling to grow their economies in some E.U. nations - notably France, Greece, Spain, Italy, and Portugal - face losses or low profits, fragmented markets, and the inefficiencies of model proliferation. The E.U. auto industry must figure out ways to better match production capacity to market demand, while simultaneously investing in new potentially strong product areas (for example, small SUVs and crossovers) and in new automobile technologies (PWC, 2016).

In Table 2 we can see turnover for the automotive industry (especially for: Manufacture of motor vehicles, trailers, and semi-trailers) - total annual data. The Turnover Index is a business cycle indicator showing the evolution of the market of goods and services in the industrial sector. It also records the evolution of turnover over longer periods of time. The turnover of industry index is not deflated. It is, therefore, the objective of this indicator to measure the market activity in the industrial sector in value. Industrial turnover is compiled as a "fixed base year Laspeyres type volume-index". The current base year is 2010 (Index $2010=100)$ (Eurostat, 2017).

The rest of European countries (CY, HR, IR, LU, MK, MT, RS, SK, SL) didn't provide specific data to Eurostat, because they have minimum automotive companies.

In most cases, we can identify a gradual increase in this indicator, which is a positive phenomenon for the economy of the European Union. Norway is the exception; one representative reported a serious decline.

\subsection{The automotive industry in the Czech Republic}

In the Czech Republic, the number of 1,000,000 motor vehicles manufactured was exceeded in September 2016. Totally, 1,002,603 pieces of all types of motor vehicles were produced from January to September 2016, representing an increase by $7.2 \%$ for the same reference period of 2015. The category of passenger cars participated the most. All three manufacturers of passenger cars reported year-over-year production increase in the Czech Republic (SDA, 2016). 
Table 2 Turnover in Automotive Industry (total - annual data) (Eurostat, 2017)

\begin{tabular}{|c|c|c|c|c|c|c|c|c|c|c|c|c|}
\hline & $\mathrm{BE}$ & BG & $\mathrm{CZ}$ & DK & $\mathrm{DE}$ & $\mathrm{EE}$ & GR & ES & FR & IT & LV & LT \\
\hline 2012 & 115.0 & 89.8 & 121.6 & 110.6 & 110.4 & 111.5 & 64.0 & 96.5 & 96.5 & 95.7 & 171.8 & 177.6 \\
\hline 2013 & 107.6 & 110.9 & 126.4 & 102.1 & 111.3 & 110.3 & 60.9 & 102.8 & 92.6 & 91.5 & 173.2 & 212 \\
\hline 2014 & 111.8 & 141.9 & 145.5 & 96.9 & 118.4 & 113.2 & 64.5 & 113.5 & 92.3 & 103 & 183 & 249 \\
\hline 2015 & 105.2 & 155.2 & 162.8 & 101.2 & 128.6 & 123.3 & 70.7 & 130.9 & 97.7 & 124 & 178.7 & 249.2 \\
\hline 2016 & 105.6 & 172.8 & 177.4 & 126 & 128.7 & 122 & 72.1 & 140.3 & 101 & 131 & 195.7 & 330.2 \\
\hline & $\mathrm{HU}$ & $\mathrm{NL}$ & $\mathrm{AT}$ & $\mathrm{PL}$ & $\mathrm{PT}$ & $\mathrm{RO}$ & FI & $\mathrm{SE}$ & $\overline{\mathrm{UK}}$ & $\mathrm{NO}$ & TR & \\
\hline 2012 & 122.4 & 113.7 & 111.2 & 115.1 & 108.7 & 136.5 & 122.4 & 101.3 & 118.9 & 88.3 & 129 & \\
\hline 2013 & 143.5 & 105.7 & 121.3 & 122.3 & 103.1 & 167.3 & 126.2 & 102.7 & 130.7 & 96.8 & 152.9 & \\
\hline 2014 & 174.1 & 109.3 & 124.4 & 126.1 & 111.5 & 180.3 & 131.6 & 103.8 & 139.6 & 103.2 & 171.6 & \\
\hline 2015 & 202.6 & 131.1 & 126.1 & 138.5 & 118.6 & 199.2 & 144 & 124.5 & 147.7 & 111.8 & 213.9 & \\
\hline 2016 & 203.3 & 164.1 & 131.2 & 154.8 & 117.3 & 231.2 & 151.5 & 143 & 161 & 89.3 & 247.5 & \\
\hline
\end{tabular}

The retail sector in the Czech Republic was again boosted by revenues collected from the motor industry; however, the growth dynamics slightly slowed-down to $13.3 \%$. Sales of new cars followed a positive trend, beginning already in 2014, when - based on a higher demand from population and company sector renewing its vehicle fleet - the demand for this assortment was dramatically relaunched.

A positive development in car industry was still influenced by the increase in foreign and domestic demand (foreign purchase orders increased by $38.0 \%$, domestic by $18.0 \%$ ). Manufacture of trucks and buses reported growth as well. Performance of the industry confirmed high competitiveness of domestic producers; a significant share of the production was delivered to foreign customers (such as a majority of TPCA production targets at foreign customers).

According to the statistic of "Sdružení automobilového průmyslu" (Automotive Industry Association), production of passenger and light commercial vehicles increased on a yearover-year basis in the second quarter 2016 by $15.0 \%$ (participating in the total production of motor vehicles by $99.6 \%$ ). The highest increase in production (by $26.3 \%$ ) reached the major Czech car maker ŠKODA-AUTO (participating in the production of passenger and light commercial vehicles by $56.7 \%$ ). TPCA production increased by $14.7 \%$ (share $17.1 \%$ ). The second largest Czech car maker HYUNDAI increased its production by $12.5 \%$ (share $26.2 \%$ ).

Production of trucks, where the only producer in the Czech Republic is the company TATRA, increased on a yearover-year basis by $46.3 \%$. Production of buses increased by $2.2 \%$; however, only in the company IVECO by $6.3 \%$, whereas SOR bus producer reported fall by $24.3 \%$.

For exporters, in addition to the weakened Czech currency, a positive situation in the European car markets supported especially traditional export of machines and transport means, reaching its maximum in June this year.

From the point of commodity structure of the trade of the Czech Republic, machines and transport means accounted for the main export and import items, traditionally contributing to the good results of the Czech foreign trade. They profited from a strong foreign demand; their export increased in the second quarter of 2016 on a yearover-year basis by $8.1 \%$; their dominant share in the total export increased on a year-over-year basis by 1.7 percentage points to $56.8 \%$.

Trading with machines and means of transport generated the highest year-over-year trade surplus and, at the same time, reported the highest absolute year-over-year export increase CZK to 43.2 billion. Road vehicles, the export of which strengthened by CZK 30.6 billion represented the largest sub-group of machines and transport vehicles. The most important sub-group of road vehicles (personal cars) profited from a strong foreign demand. Their export was up by $19.6 \%$ to CZK 126.4 billion on a year-over-year basis.

Automotive Industry Association reported a very positive trend in the number of employees and their salaries in 2016. The number of employees increased on a yearover-year basis by $4.5 \%$, amounting totally to 118,000 people. Their average monthly income reached nearly CZK 35,000 , which is by $30 \%$ more than the average in the Czech Republic. Compared to 2015, this figure represents a year-over-year increase of $3.7 \%$. The high productivity of labor in the car industry and the effort of companies to manufacture products with a higher added value enable a regular increase in salaries and salary level above the national average (AutoSAP, 2017). 
In the future, new trends emerging in the automotive industry will play an important role, such as: alternative fuel vehicles (electricity, gas, hydrogen), new technologies (mobile-phone connected cars), digital manufacturing (a connection between all intelligent devices, production lines and products, all production systems, warehouses, logistics and service into a single intelligent information network, within the framework of which smart appliances of customers, products and suppliers will communicate together without any human help and will respond to needs of clients in real time), tougher ecological and safety standards (stricter $\mathrm{CO}_{2}$ emission standards as well as tightening safety standards), continuing decrease in costs resulting in higher production efficiency etc. Producers must be able to respond adequately and still stay competitive. For instance, a car manufacturer Škoda has outlined its plans for the production of alternative fuel cars; in 2025, electric cars or hybrids would account for one-fourth of the production of the car manufacturer (CSAS, 2015).

\section{Methodology}

The main aim of this paper is to find key indicators in grouped factors in the field of financial performance of automotive companies because performance is a crucial issue for all individuals and organizations (as one of the most important parts of engineering industry). The partial aim of the paper is to identify the relationship between observed factors and company size and NACE classification.

The main hypothesis suggests dependence between the realization of individual activities and their performance in connection with automotive industry. At present days, automotive has become the very important part of industrial production. Data have been gathered from Amadeus database and processed by the statistical program IBM SPSS Statistics 24; subsequently:

1. factor analysis,

2. dependency between two nominal variables by means of contingency tables and Pearson's chisquared test, and

3. correspondence analysis have been studied.

The conditions for a choice of companies:

1. geographical location;

2. dividing according to corporate size;

3. classification of economic activities according to NACE classification, reduced to the automotive sector.
According to selected NACE group, the basic population has been defined for the individual European region. The population sample of automotive companies consists 422 subjects in four parts of Europe (include twenty-five countries) (see Table 3).

Factor analysis is based on the selection of correlation and partial correlation coefficients. The correlation coefficient represents the closeness of linear dependence of individual variables and partial correlation coefficients. The partial correlation coefficient shows a similarity of two variables in such a situation that the other variables are assumed constant. If it is possible to explain the dependence of variables using common factors, the partial correlation coefficients are very small, close to zero. To assess the suitability of the factor analysis, two tests can be used (Tarnanidis et al., 2015; Conti et al., 2014):

- Kaiser-Meier-Olkin (KMO) is a coefficient which could reach values between 0 and 1 (it rates squares sum of the correlation coefficients and squares sum of the correlation and partial coefficients).

- The use of Bartlett's sphericity test lies in testing the null hypothesis stating that the correlation matrix of variables is unit (on diagonal, there are only ones, others are zeros).

Factor extraction methods represent the way to determine the number of factors and the size of their factor loads. For the application of factor analysis, there was used the method of principal components, which provides non-correlated factors, sorted by their variance. Analysis of principal components tries to reduce the number of variables to express variance of original variables. If there are high correlations between individual variables, the total variance can be expressed by one main component. This method gives a clear factor solution where the variable exhausts the highest possible percentage of variance (Hrach and Mihola, 2006).

Table 3 Pivot table of company size and European region

\begin{tabular}{lccccc}
\hline & Western & Southern & Northern & Eastern & Total \\
\hline Micro & 5 & 64 & 32 & 22 & 123 \\
Small & 12 & 48 & 17 & 12 & 89 \\
Medium & 11 & 34 & 14 & 14 & 73 \\
Large & 24 & 21 & 23 & 10 & 81 \\
Missing & 18 & 15 & 6 & 17 & 56 \\
Total & 73 & 182 & 92 & 75 & 422 \\
\hline
\end{tabular}


For the purposes of verification of the factor analysis, Cronbach's alpha indicator must be used. This indicator is understood as a reliability coefficient, used as a kind of analogy with the correlation coefficient. Normally, values oscillate in the interval $\langle 0 ; 1\rangle$. Zero, as the extreme value, describes the situation in which individual variables are uncorrelated. On the other hand, the value 1 describes correlated variables. When the value is closer to 1, a higher degree of conformity is reported (Hrach and Mihola, 2006; Cronbach, 1951; Řehák and Brom, 2016).

However, high Cronbach's alpha does not imply that the measure is dimensionless. If, in addition to measuring internal consistency, you wish to provide evidence that the scale in question is dimensionless, additional analyses can be performed. Exploratory factor analysis is one of the methods to check dimensionality. Cronbach's alpha is not a statistical test; it is a coefficient of reliability (or consistency). The value could be expressed as the function of a number of test items and the average inter-correlation among the items. Below, for conceptual purposes, we show the formula for the standardized Cronbach's alpha:

$\alpha=\frac{N \times \bar{c}}{v+(N+1) \times \bar{c}}$

where $N$ equals the number of items; $c$-bar is the average inter-item covariance among the items; $v$-bar equals the average variance.

The values of Cronbach's alpha could be from 0 to 1 . If the values are close to 0.5 , it signifies a bad level of internal consistency. Over 0.7 means that the value is acceptable and values close to 1 are excellent. A "high" value of the alpha is often used (along with substantive arguments and other statistical measures) as evidence that the items measure an underlying (or latent) construct (Hinton et al., 2004).

Correspondence analysis describes a relation between both two nominal variables in a pivot table and individual categories. In a pivot table, there is category combination which should become significant or not. If any categories are similar or associated, there are located in graph near themselves. Correspond analysis itself is focused on association rate, usually by chi-square measure. There are nominal variables as input into correspondence analysis, and kind of premise, that there is no ordering between variables (McGarigal et al., 2000; Beh, 2008; 2010). Correspond analysis processes dimensional homogenous data which consist only positive values or zeros. Chi-square range has become coefficient which excludes zeros and helps to define relations between rows and columns.
Calculation of correspondence analysis includes three

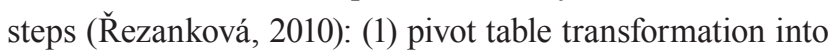
table with support of Pearson chi-square; (2) individual value decompositions are applied to defined table, then there are calculated new values and new vectors; (3) new matrix operations serve as input to graph design. The basis for two-dimensional pivot tables is data matrix $n \times 2$, in which categorical variable $A$ get $r$ values $\left(a_{1}, a_{2}, \ldots a_{r}\right)$ and categorical variable $B$ get $s$ values $\left(b_{1}, b_{2}, \ldots b_{s}\right)$. Due to realized observation, there is created a table by two-dimensional separations of both variables. In the table is used $n_{i j}$ frequency, which represents intersect of both variables. This $n_{i j}$ provides a number of observations, where are both $a_{i}$ and $b_{j}$. Except for $n_{i j}$ there are used marginal frequency $n_{i+}$, where $o w$ observation with $a_{i}$ value is observed (a similar approach is for $n_{j+}$ in a column). In that table there are applied relative frequencies (Beh, 2010; Kudlats et al., 2014):

$\sum_{i=1}^{r} \sum_{j=1}^{s} p_{i j}=\sum_{i=1}^{r} p_{i+}=\sum_{j=1}^{s} p_{+j}=1$.

A set structure is described by contingent relative frequency $p_{j / i}$ in two possible ways:

1. from point of variable $B$ view, if variable $A$ reaches value $a_{i}$;

$p_{i / j}=\frac{n_{i j}}{n_{i+}}=\frac{p_{i j}}{p_{i+}}$

2. from point of variable $B$ view, if variable $A$ reaches value $a_{j}$;

$p_{i / j}=\frac{n_{i j}}{n_{+j}}=\frac{p_{i j}}{p_{+j}}$.

Any changes in these values transform variable dependence, which is usually measured by Pearson chi-square test (Beh, 2008):

$\chi^{2}=\sum_{i=1}^{r} \sum_{j=1}^{s} \frac{\left(n_{i j}-\frac{n_{i+} \times n_{+j}}{n}\right)^{2}}{\frac{n_{i+} \times n_{+j}}{n}}=n \times \sum_{i=1}^{r} \sum_{j=1}^{s} \frac{\left(p_{i j}-p_{i+} \times p_{+j}\right)^{2}}{p_{i+} \times p_{+j}}$.

After estimating the theoretical frequencies there is designed chi-square statistics. This statistic has chisquare distribution and a number of degrees of freedom $(r-1)(s-1)$. On this basis, it is decided if exist dependency between variables in the population, and by using correspondence analysis is also possible to determine the structure of dependence (Beh, 2010; Kudlats et al., 2014). 


\section{Results}

Based on the economic data from Amadeus database, it is evident that companies commonly use traditional financial indicators for measurement of their own performance. These indicators were analyzed:

- $x_{1}$ - Cash flow [th EUR];

- $x_{2}-P / L$ for period (Net income) [th EUR];

- $x_{3}$ - Operating revenue [th EUR];

- $x_{4}-\mathrm{ROA}$ using $P / L$ before tax $[\%]$;

- $x_{5}-\mathrm{ROE}$ before tax [\%];

- $x_{6}$ - Operating $P / L($ EBIT) [th EUR];

- $x_{7}-$ Gross profit [th EUR];

- $x_{8}-$ Shareholder funds [th EUR].

Based on the statistical characteristics of the examined groups the conclusions could be presented as an approximate result, limited by the resulting reliability. In the results of the paper, there are characteristics of research barriers and future research possibilities.

For the purpose of factor analysis, the value of KaiserMeier-Olkin test should reach the value of at least 0.5 (value range is between 0 and 1). In order to assess whether it is possible to use the factor analysis, Kaiser-MeyerOlkin method (KMO) and Bartlett's test of sphericity have been used. The KMO method is based on selective correlation and partial correlation coefficients. For the indicators in factor analysis, KMO is observed according to the highest level of acceptance, which means that the performed level of usefulness of the factor analysis reaches high value. Bartlett's test of sphericity is a statistical test used to examine the hypothesis that the variables are correlated or uncorrelated. Value for KMO test was reached by 0.691 and for Bartlett's test by 0.000 . Therefore, factor analysis could be applied to the data

The total variance of the performance indicators is explained by means of eigenvalues, representing the total variance explained by each factor. The eigenvalues show that only three items have reached the minimum value of 1. From this point of view, Extraction Sums of Squared Loadings with cumulative percentage are important. Factor analysis has extracted different numbers of factors, which explains variances of all cases $(95.367 \%)$.

The main result of factor analysis in the area of financial metrics is a rotated matrix, indicating the strength of individual variables saturating individual factors we found (for rotation there was used Varimax method). For defining parameters there is necessary to use component matrix (Table 5).
Results of factor analysis provide three factors, from which are acceptable values of Cronbach's alpha for two of them. The last factor has Cronbach's alpha value under minimal acceptable value (under 0.500). Final values for calculating acceptable factors need the transformation of individual coefficients. These coefficients express the significance of the used elements. Their sum total must be 1 . The individual factor indexes have been defined by the procedures as Eq. (6) and Eq. (7):

$$
\begin{aligned}
& I 1=0.262 \times x_{1}+0.245 \times x_{3}+0.248 \times x_{7}+0.245 \times x_{8} \\
& I 2=0.475 \times x_{2}+0.525 \times x_{6} .
\end{aligned}
$$

These indices can be calculated for the individual automotive company and on the basis of their results a list of businesses can be compiled. Indices can determine important factors of business, playing the key role in achieving the set of objectives. Proposed financial performance indicators should help companies to demonstrate a progress towards the objectives of sustainability (basic statistics of indexes are in Table 4).

Pivot tables have been employed to find possible dependencies between observed factors and company size and region of a company, for results of the dependency tests see Table 6. Results of the dependence examination in individual variable categories are depicted in the following results of Pearson's chi-square test.

Maintaining the $\%$ reliability of the test, the values for connection between individual factors and company size have been determined within 0.05 , which represents $5 \%$ reliability level. Established values of Pearson's test for the variables are shown in Table 5 (i.e., less than 0.05). Therefore, that brings us to the conclusion that an alternative hypothesis is applied - there are dependencies between all observed factors and company size for all observed indexes. Past results have revealed the relationship between indexes and company size and European region. Subsequently, a degree of such dependence has been examined. To that end, the intensity of dependence determined by means of Contingency coefficient.

Table 4 Descriptive statistics of observed indices

\begin{tabular}{lcc}
\hline & Index 1 & Index 2 \\
\hline Mean & 6212592.165 & 56851.8347 \\
Median & 186694.2203 & 58.4104 \\
Variance & $3.493 \times 10^{14}$ & $4.919 \times 10^{11}$ \\
Std. deviation & 18688816.14 & 701340.4134 \\
\hline
\end{tabular}


Table 5 The component matrix of evaluated indicators

\begin{tabular}{|c|c|c|c|c|c|c|c|c|c|}
\hline & $x_{1}$ & $x_{2}$ & $x_{3}$ & $x_{4}$ & $x_{5}$ & $x_{6}$ & $x_{7}$ & $x_{8}$ & Cronbach's alpha \\
\hline Index 1 & 0.988 & & 0.925 & & & & 0.934 & 0.926 & 0.761 \\
\hline Index 2 & & 0.233 & & & & 0.258 & & & 0.944 \\
\hline Index 3 & & & & 0.252 & 0.301 & & & & 0.488 \\
\hline
\end{tabular}

Table 6 Pearson's test of the relationship between individual indexes, company size, and European region

\begin{tabular}{llcccc}
\hline \multirow{2}{*}{ Value } & & \multicolumn{2}{c}{ Corporate size } & \multicolumn{2}{c}{ European region } \\
& & Value & Asymp. Sig. (2-sided) & Value & Asymp. Sig. (2-sided) \\
\hline \multirow{2}{*}{ Index 1 } & Pearson chi-Square & 28.268 & 0.001 & 19.134 & 0.024 \\
& Contingency coefficient & 0.658 & & 0.574 & \\
\multirow{2}{*}{ Index 2 } & Pearson chi-Square & 271.558 & 0.000 & 27.283 & 0.001 \\
& Contingency coefficient & 0.653 & & 0.246 & \\
\hline
\end{tabular}

The intensity of dependence ranges between $\langle 0 ; 1\rangle$. That means that the higher the absolute value, the greater the intensity of dependence. Table 5 shows that observed indexes are closely connected within the size of the company and region of Europe - all significance values are in $5 \%$ of the limit of error. The intensity of the dependence is given by Contingency coefficient, which provides a view of this connection. All four defined connection between observed indexes and corporate size and region reach accurate values and there is confirmed dependency between them.

Load indicators (Mass) indicate load line which represents the percentage of information across the table in an appropriate category. That loads are obtained as the ratios of the row and column marginal frequencies $\left(n_{i+}\right.$; $\left.n_{+\mathrm{j}}\right)$ in the whole table of individual categories $(n)$.

A score in dimension describes individual variables score in two main dimensions. These dimensions don't represent any specific area, because they are reduced to from multi-dimension space. All data in rows and columns have been usually in multi-dimension space, which is reduced to two. Providing information of raw data has not been modified after multi-dimension space reduction of these variables. Inertia indicator represents the share comprehensive information on the profile (on the relevant point). This characteristic is independent of the number of dimensions. Correspondence map includes a graphical representation of both row and column categories according to their dimension scores (Hebák et al., 2007; D'Esposito et al., 2014).

Results of correspondence analysis are included in graphs, which illustrate relations between individual categories and variables. Fig. 1 shows row and column points of the two-dimensional solution. By using symmetrical normalization simplifies examining the
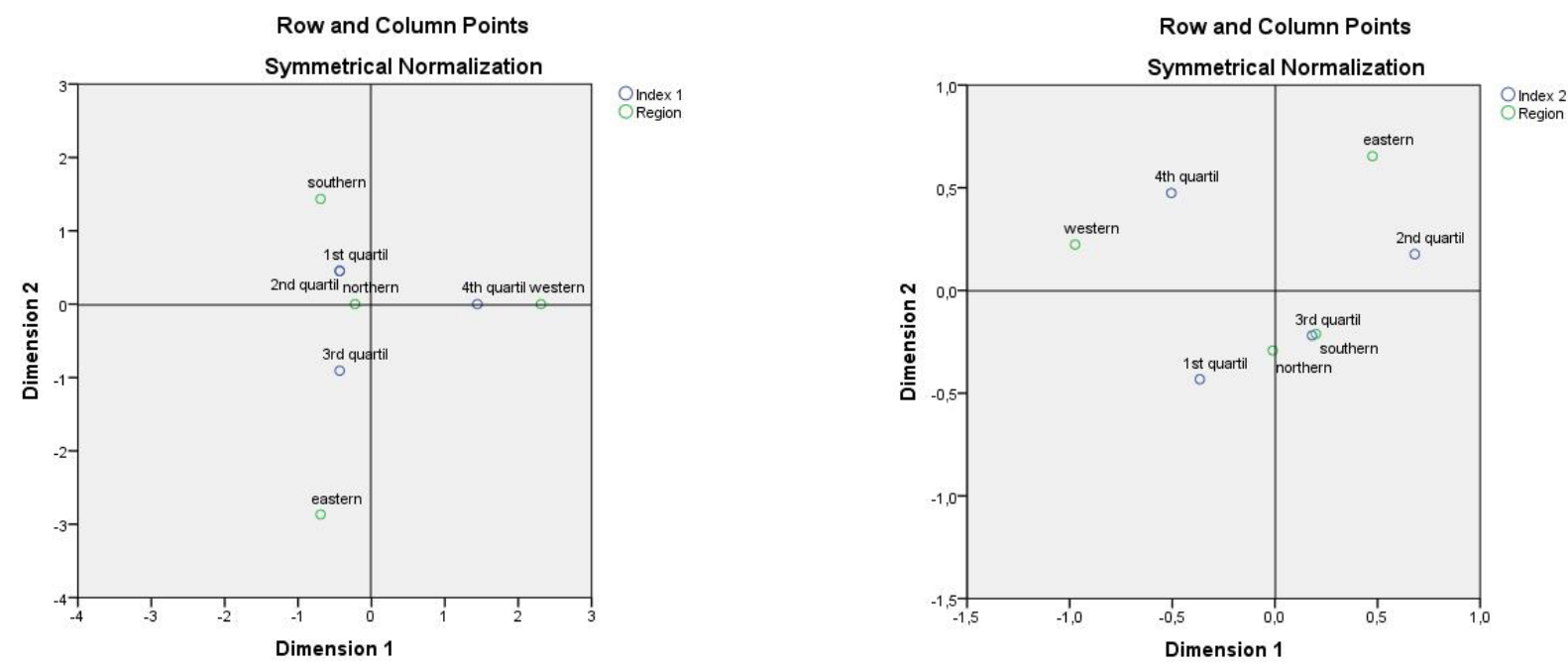

Fig. 1 Symmetrical correspond map of index $1 / 2$ and region 
relationships between individual categories of the variables. Both dimension 1 and dimension 2 provide only "describing space", in which were the application of observed indexes and size of a company. Gained results are confirmed by significance value of chi-square test. According to computation, this significance is at value 0.024. Fig. 1 displays the relations among the individual categories and variables, specific links among European region and index 1 , is the output of the correspondence analysis. Two separate groups of categories can be identified. We can say that western companies are at the top of the performance level because they are in the fourth quartile of the values. Vice versa, southern companies incline to the first quartile, what means they are not focused on performance measurement. A similar situation is for the relation between European regions and Index 2. This relation is confirmed by chi-square significance by value 0.001. In this connection, there are located, three separate groups.

We can say that western companies are at the top of the performance level because they are in the fourth quartile of the values. Otherwise, eastern companies incline to the second quartile, what means they are not so much focused on performance measurement.

\section{Conclusions}

The main aim of this paper is to find key indicators in grouped factors in the field of financial performance of automotive companies because performance is a crucial issue for all individuals and organizations. The main condition for a choice of companies was NACE classification. The article itself was focused on all-sized companies in the region of European Union.

\section{References}

Allio, M. (2006) "Metrics that matter: seven guidelines for better performance measurement", Handbook of Business Strategy, 7(3), pp. $255-263$. https://doi.org/10.1108/10775730610618918

AutoSAP (2017) "Růst automobilového průmyslu v roce 2016 přinesl růst pracovních příležitostí i mezd", (The growth of the automotive industry in 2016 has brought employment and wage growth) [pdf] Available at: http://www.autosap.cz/sfiles/TI6_2017_FIN. pdf [Accessed: 21 June 2017] (in Czech)

Beh, E. J. (2008) "Correspondence analysis of aggregate data: The $2 \times 2$ table", Journal of Statistical Planning and Inference, 138(10), pp. 2941-2952.

https://doi.org/10.1016/j.jspi.2007.11.004
Based the Richard et al. (2009) we have three types of indicators:

1. accounting measures,

2. financial market measures, and

3. mixed accounting / financial market measures.

In the paper, most of the analyzed indicators fall into the first group, which is focused on the financial results of enterprises. Empirical research deals with the main statistical method - factor analysis - that is usually used for the reduction of surveyed indicators. Within the framework of the research, we have found two indexes: Index 1 contains the indicators: Cash flow, Operating revenue, Gross profit and Shareholder funds; Index 2 is made up of $P / L$ for a period (Net income) and Operating $P / L$ (EBIT). These indexes have also been confirmed on the basis of Cronbach's alpha.

At the same time, dependence among the above-mentioned factors, company size, and European region was tested. Observed indexes are closely connected within the size of the company and region - all significance values are in $5 \%$ of limit error. The intensity of the dependence by the Contingency coefficient was defined between all the selected conditions. Than correspond map was constructed, where we can see relations between individual categories and variables. Gained results are confirmed by significance value of chi-square test, this significance value is 0.024 .

These indexes are intended especially for owners but could be for investors, and other stakeholders to support their decision-making. The inclusion of factors means that strengths and weaknesses of companies can be more readily identified, and permits a broader view of the company than the one-dimensional methods based only on their economic performance.

Beh, E. J. (2010) "Elliptical confidence regions for simple correspondence analysis", Journal of Statistical Planning and Inference, 140(9), pp. 2582-2588. https://doi.org/10.1016/j.jspi.2010.03.018

Colasse, B. (2009) "Analiza financiară a întreprinderii" (Financial analysis of the enterprise), 5th ed., Editura Tipo Moldova, Iaşi, Romania.

Conti, G., Frühwirth-Schnatter, S., Heckmanc, J. J., Piatek, R. (2014) "Bayesian exploratory factor analysis", Journal of Econometrics, 183(1), pp. 31-57. https://doi.org/10.1016/j.jeconom.2014.06.008

Cronbach, L. J. (1951) "Coefficient alpha and the internal structure of tests", Psychometrika, 16(3), pp. 297-334. https://doi.org/10.1007/BF02310555 
CSAS (2015) "Měsíčník EU aktualit", (EU monthly news) [pdf] Česká spořitelna, Prague, Czech Republic, Available at: http://www.csas.cz/static_internet/cs/Evropska_unie/Mesicnik_ EU_aktualit/Mesicnik_EU_aktualit/Prilohy/mesicnik_2015_09. pdf [Accessed: 25 June 2017] (in Czech)

D'Esposito, M. R., de Stefano, D., Ragozini, G. (2014) "On the use of Multiple Correspondence Analysis to visually explore affiliation networks", Social Networks, 38, pp. 28-40. https://doi.org/10.1016/j.socnet.2014.01.003

Ehrenberger, M., Koudelková, P., Strielkowski, W. (2015) "Factors Influencing Innovation in Small and Medium Enterprises in the Czech Republic", Periodica Polytechnica Social and Management Sciences, 23(2), pp. 73-83 https://doi.org/10.3311/PPso.7737

Elena, N. I. (2012) "Company Performance Measurement and Reporting Methods", The Annals of The University of Oradea, Economic Science, 21(2), pp. 700-707.

European Commision (n.d.) "Automotive industry", [online] Available at: https://ec.europa.eu/growth/sectors/automotive_en [Accessed: 15 March 2017]

Eurostat (2017) "Turnover in industry, total - annual data", [online] Available at: http://appsso.eurostat.ec.europa.eu/nui/show.do?dataset=sts_intv_a\&lang=en [Accessed: 25 July 2017]

Germain, R., Dröge, C., Christensen, W. (2001) "The mediating role of operations knowledge in the relationship of context with performance", Journal of Operations Management, 19(4), pp. 453-469. https://doi.org/10.1016/S0272-6963(00)00067-X

Harvey, J. (2005) "KPIs - The Broader Strategic Context", Credit Control, 26(4), pp. 65-66.

Hebák, P., Hustopecký, J., Pecáková, I., Průša, M., Řezanková, H., Svobodová, A., Vlach, P. (2007) "Vícerozměrné statistické metody", (Multidimensional statistical methods) 1st ed., Informatorium, Prague, Czech Republic. (in Czech)

Helfert, E. (2006) "Tehnici de analiz financiar: ghid pentru crearea valorii", (Techniques of financial analysis : a guide to value creation) 11th ed., BMT Publishing House, Bucharest, Romania. (in Romanian)

Hinton, P. R., McMurray, I., Brownlow, C. (2004) "SPSS explained", 1 st ed., Routledge, Hove, United Kingdom.

Hrach, K. Mihola, J. (2006) "Metodické př́stupy ke konstrukci souhrnných ukazatelü", (Methodological approaches to the construction of aggregate indicators) Statistika, 86(5), pp. 398-418. (in Czech)

Holsapple, C. W., Wu, J. (2011) "An elusive antecedent of superior firm performance: The knowledge management factor", Decision Support Systems, 52(1), pp. 271-283. https://doi.org/10.1016/j.dss.2011.08.003

Kerzner, H. (2011) "Project Management Metrics, KPIs, and Dashboards: A Guide to Measuring and Monitoring Project Performance", 1st ed., John Wiley \& Sons, New Jersey, USA.

Kirby, J. (2005) "Toward a Theory of High Performance", Harvard Business Review, 83(July-August), pp. 30-39.

Kudlats, J., Money, A., Hair, J. F. (2014) "Correspondence analysis: A promising technique to interpret qualitative data in family business research", Journal of Family Business Strategy, 5(1), pp. 30-40. https://doi.org/10.1016/j.jfbs.2014.01.005

March, J. G., Sutton, R. I. (1997) "Organizational Performance as a Dependent Variable", Organization Science, 8(6), pp. 698-706.
McGarigal, K., Cushman, S. A., Stafford, S. (2000) "Multivariate Statistics for Wildlife and Ecology Research", 1st ed., Springer, New York, USA.

Mohamed, R., Hui, W. S., Rahman, I. K. A., Aziz, R. A. (2014) "The Relationship between Strategic Performance Measurement System and Organizational Capabilities: The Role of Beliefs and Boundary Control Systems", Asian Journal of Business and Accounting, 7(1), pp. 107-142.

Monea, M., Guță, A. J. (2011) "The Relevance of the Performance Indicators in Economic and Financial Diagnosis", Annals of the University of Petroşani, Economics, 11(4), pp. 207-214.

Neely, A. (2004) "Business performance measurement: Theory and practice", 1st ed., University Press, Cambridge, United Kingdom.

Parmenter, D. (2010) "Key Performance Indicators: Developing, Implementing, and Using Winning KPIs", 2nd ed., John Wiley \& Sons, New Jersey, USA.

PWC (2016) "Auto Industry Trends 2016", [online] Available at: http://www.strategyand.pwc.com/trends/2016-auto-industry-trends [Accessed: 25 July 2017]

Richard, P. J., Devinney, T. M., Yip, G. S., Johnson, G. (2009) "Measuring Organizational Performance: Towards Methodological Best Practice", Journal of Management, 35(3), pp. 718-804. https://doi.org/10.1177/0149206308330560

Řehák, J., Brom, O. (2016) "SPSS: Praktická příručka", (SPSS: Practical guide) 1st ed., Computer Press, Brno, Czech Republic. (in Czech).

Řezanková, H. (2010) "Analýza dat z dotazníkových šetření", (Analysis of data from questionnaire surveys) 2nd ed., Professional Publishing, Praha, Czech Republic. (in Czech).

Samsonowa, T., Buxmann, P., Gerteis, W. (2009) "Defining KPI Sets for Industrial Research Organizations - A Performance Measurement Approach", International Journal of Innovation Management, 13(2), pp. 157-176. https://doi.org/10.1142/S1363919609002248

SDA (2016) "Česko letos vyrobilo 1 mil. motorových vozidel", (The Czech Republic produced 1 million vehicles this year) [online] Available at: http://portal.sda-cia.cz/clanek.php?id $=5725 \& \mathrm{v}=\mathrm{m}$ [Accessed: 08 July 2017] (in Czech)

Smith, D. A. (2008) "Implementing indicators for IT service management", 1st ed., Van Haren Publishing, Zaltbommel, Netherland.

Sebestova, J. (2012) "Entrepreneurial dynamics - can it be effective?", Periodica Polytechnica Social and Management Sciences, 20(1), pp. 23-28. https://doi.org/10.3311/pp.so.2012-1.03

Šiška, L., Lízalová, L. (2011) "Výběr ekonomických ukazatelů pro měření dlouhodobé výkonnosti podniku", (Selection of economic indicators to measure long-term business performance ) Journal of Competitiveness, 3(1), pp. 4-14. (in Czech)

Tarnanidis, T., Owusu-Frimpong, N., Nwankwo, S., Omar, M. (2015) "A confirmatory factor analysis of consumer styles inventory: Evidence from Greece", Journal of Retailing and Consumer Services, 22, pp. 164-177. https://doi.org/10.1016/j.jretconser.2014.07.001

Zakaria, Z., Yaacob, M. A., Yaacob, Z., Noordin, N., Sawal, M. Z. H. M., Zakaria, Z. (2011) "Key Performance Indicators (KPIs) in the Public Sector: A Study in Malaysia", Asian Social Science, 7(7), pp. 102-107. 